\title{
Food Insecurity and the Rising Urbanisation in Africa: Can ICT Revolution Bridge the GAP?
}

\author{
Isaac B. Oluwatayo, ${ }^{1}$ Ayodeji $0.0 j{ }^{2}$ \\ ${ }^{1}$ University of Limpopo, Sovenga, South Africa \\ 2University of Ibadan, Ibadan, Nigeria \\ isaac.oluwatayo@ul.ac.za, ayodejiojo7591@gmail.com
}

\begin{abstract}
The task of reducing food insecurity in Africa is very challenging. This is because of the changing conditions such as adverse climate change impacts. This study examined food insecurity, urbanisation and ICT in Africa. The paper employed a combination of both secondary and historical information obtained from different sources (UNHCR, FAO, Mo Ibrahim Foundation etc). Analytical method used include descriptive statistics such as charts. Food security indices in Africa is alarming and disturbing. One in four people in Africa do not have access to food in adequate quantities and one in five African children are underweight. African agriculture is rendered unattractive by low productivity hence the exodus of labour from rural to urban areas. Africa is the most rapidly urbanising continent in the world with enabling factors comprising of infrastructure deficits in rural areas, dearth of employment opportunities and glamour of city life. However, Africa's urban centres are not immune to the challenges inducing rural-urban migration in the first place. In fact, youth unemployment in Africa is 6 times higher in urban areas than in rural areas. About 72percent of urban dwellers live in slums with the most of them having no access to basic amenities. These culminated in what is regarded in literature as 'urbanisation of poverty'. Migrants are generally scapegoated as the causes of crimes, violence and even unemployment in urban areas. Therefore, they are subjected to sub-human living conditions. Information and Communication Technology (ICT) is particularly critical to the achievement of food security in Africa. This is because of the huge gap between markets and farmers which it is capable of filling. The paper therefore recommends increased but monitored investments in infrastructure in Africa in order to make rural areas more attractive and discourage rural-urban migration. There is also the need to provide favourable micro and macro-environment for businesses to grow especially in rural Africa.
\end{abstract}

Keywords: Africa, Development, Food insecurity, ICT revolution, Rural-urban drift, Urbanization

\section{Introduction}

Background of the Study: Food security occupies a central position in the global policy discourse (Ruhiiga, 2013). In fact, it is the second goal in the Sustainable Development Goals which is to end hunger, achieve food security and improved nutrition and promote sustainable agriculture. The Catholic Relief Agency defines food security as a situation where people have physical and economic access to sufficient food to meet their dietary needs for a productive and healthy life today without sacrificing investments in livelihood security tomorrow (Ubong et al., 2009). The most widely cited definition in literature is the 1996 World Food Summit Plan of Action which states that food security exists when all people, at all times, have physical and economic access to sufficient, safe and nutritious food to meet their dietary needs and food preferences for an active and healthy life (Harris, 2014). Although, urbanisation has been defined in many ways. It is defined as the process of agglomeration of people in a human settlement such that the settlement graduates from a level of complexity (economic, social and physical) to the other (Jelili, 2012). Urbanisation can also be viewed as the process by which rural areas are transformed into urban areas which involves population rise stemming from migration and natural expansion (Waugh, 1990). Most of the definitions of urbanisation in previous studies have some concepts that unite them. The concepts include (i) a demographic process (ii) necessary ingredient for economic and industrial development (iii) social change and (iv) a universal phenomenon (Hove et al., 2013). There are a lot of issues around the nature of urbanisation in Africa and its effects on food security and they have received attention in literature. However, this paper situates ICT within the context of food security and urbanisation process in Africa in order to drive inclusive and pro-poor policies.

The Current State of Food Security in Africa: There is a reduction in global hunger according to the FAO estimate. An estimated 805 million people were estimated to be chronically malnourished in 2012-2014. However, Northern Africa has a consistently low prevalence of hunger at less than 5 percent. According to Ackello-Ogutu et al., (2012), an estimated 40 percent of people in sub-Saharan Africa subsist below the poverty line with majority living in rural areas. Given the current situation and potential climate change issues, it is 
estimated that 52 million children will be malnourished by 2050 (Ackello-Ogutu et al., 2012). Meanwhile, agriculture accounts for 60 percent of employment, 15percent of exports and 20 percent of Africa's Gross Domestic Product (Ackello-Ogutu et al., 2012). However, only 5percent of the cropped area is irrigated as against 14 percent in Latin America and 37 percent in Asia (Ringler et al., 2010). Hence, the undue exposure to vagaries of weather and consequently low productivity. The proportion of food insecure people has been rising globally since 2007 food price crisis. Available estimates reveal an increase in the proportion of undernourished from 28percent in 2004-2006 to 29percent in 2008 (UN, 2009; Conceicao et al., 2011) compared to 17 percent in developing countries. An estimated 50 percent of food insecure people are smallholder farmers, 22percent are rural landless, 20percent are urban poor and 8percent depend on natural resources for their livelihoods (Bremner, 2012).

An estimated 70percent of the global poor live in rural areas with young people constituting the vast majority of the poor. Meanwhile, about 75 percent of the poor live in rural areas in South and South East Asia and subSaharan Africa (SDSN, 2013). In fact, 25percent of people who lack adequate food for healthy and active life reside in sub-Saharan Africa (FAO et al., 2014). In Africa, agricultural food productivity per capita of about 2.5percent is lower than population growth estimated at 3.6 percent hence the worsening food crisis (Ogujiuba et al., 2013). Low agricultural and food productivity in Africa is on the other hand caused by unfavourable climatic conditions, land degradation and natural disasters such as drought especially in the Horn of Africa, desertification and desert encroachment in other parts of Africa (IFAD, 2011; IFPRI, 2012). This has resulted in increased food prices thereby pushing access to food beyond the reach of the poor. Moreover, agriculture in Africa is characterised by undercapitalisation, underproduction, underemployment and low incomes. Scholars have identified a relationship between food crisis, population growth and human health (Ogujiuba et al., 2013). In fact, due to global population growth there are 840 million malnourished people in the world. Developing countries account for the bulk (799million) of the malnourished people most of which are in Asia and Africa (WHO, 1996). Poor people are particularly vulnerable to malnutrition, anaemia, vitamin A deficiency, iodine deficiency, acute respiratory infections, malaria and fatigue.

There is the challenge of multidimensional nature of food security and its relationship with issues such as climate change, trade and development that policy makers have to resolve (Masters, 2008). The issue of food security is very complex as it can be linked to poor harvests and low food stocks, floods, droughts and changing consumption patterns. Climate change worsens food insecurity in Africa (Lwasa, 2014). This occurs through delay in the onsets and early cessation of rains, rising sun intensity and wind storms consequently leading to crop failure, sub-optimal production level, high post-harvest losses and conflicts (Oluwatayo and Ojo, 2016). Hence, climate change affects social and economic development in Africa. According to Masters (2008), heavy rains and flooding has affected over 800,000 people with Ghana, Togo, Burkina Faso and Mali most affected. Drought is the main undermining factor influencing food security in Mauritania. Another climate changeinduced challenge is the increase in the incidences of pests and diseases for humans, animals and plants. While pests and diseases reduce yields and consequently income of farm families, it increases the number of days farmers spend off-farm. In terms of trade, there are challenges in Africa's regional integration plan. This can be attributed to the absence of legal and regulatory framework and capacity to implement policy decisions (Masters, 2008).

Human Immunodeficiency Virus/ Acquired Immunodeficiency Syndrome (HIV/AIDS) is another emerging threat to Africa's food security. This is because HIV significantly influences availability and health of farm labour. The disease also affects household income due to the high cost of managing it. HIV/AIDS is more prevalent among people aged 15 to 50 years who constitute the bulk of the labour force. FAO estimates that AIDS has killed seven million agricultural workers in Africa since 1985. It has the potential to kill 16 million more within the next 20 years (ICAIDS, 2001). Typically, the quantity and quality of food available to a household will decline as productive family members become sick or die. The situation is worse for childheaded households in countries like South Africa. The additional burden of caring for orphans and unproductive individuals can impact upon overall food security (ICAIDS, 2001). Conflicts in Central African Republic, North East Nigeria and Northern Mali have grave consequences on food security. Fulani herdsmen are actively destroying farmlands and engaging in attacks and reprisal attacks in almost all parts of Nigeria. This threatens already inadequate food production level. There are currently 1, 235, 294 internally displaced persons in Nigeria (UNHCR, 2015 cited in FAO, 2015). Chad currently has 17,300 refugees out of which ten 
percent battle with severe food insecurity (FAO, 2015). In West Africa, about 4,749, 000 people were food insecure between March and May 2015 (FAO, 2015).

\section{The Food Insecurity and Urbanisation Nexus in Africa}

The global population is expected to rise to 7.5 billion by 2020. Meanwhile, the developing world is expected to account for 80percent of the urban population. According to the 2014 World Urbanisation Prospects, 54percent of global population currently live in the urban areas and the number is expected to rise to 66percent by 2050 (UNDESA, 2012; Freire et al., 2014). The global urban population increased from 746million in 1950 to 3.9 billion in 2014. Africa and Asia will account for significant level of global urbanisation in near future. In fact, Africa and Asia will account for 70percent of urban inhabitants in the world by 2030 (Jelili, 2012). New cities are emerging in Africa while the existing ones are fast becoming megacities (Hove et al., 2013; Chenal, 2016). An estimated 50percent of Africa's population will be living in urban areas by 2030 (Mo Ibrahim Foundation, 2015). Africa is considered the most rapidly urbanising continent in the world (Hove et al., 2013) with an annual average growth of 3.3percent between 1990 and 2000 and 4.5 percent between 2000 and 2005 (Jelili, 2012). The percentage of African population living in urban areas is expected to increase to 56percent by 2050 (AFDB et al., 2016; Carmody and Owusu, 2016).

Figure 1: Population, Urban Population and Population Growth Rate in Africa

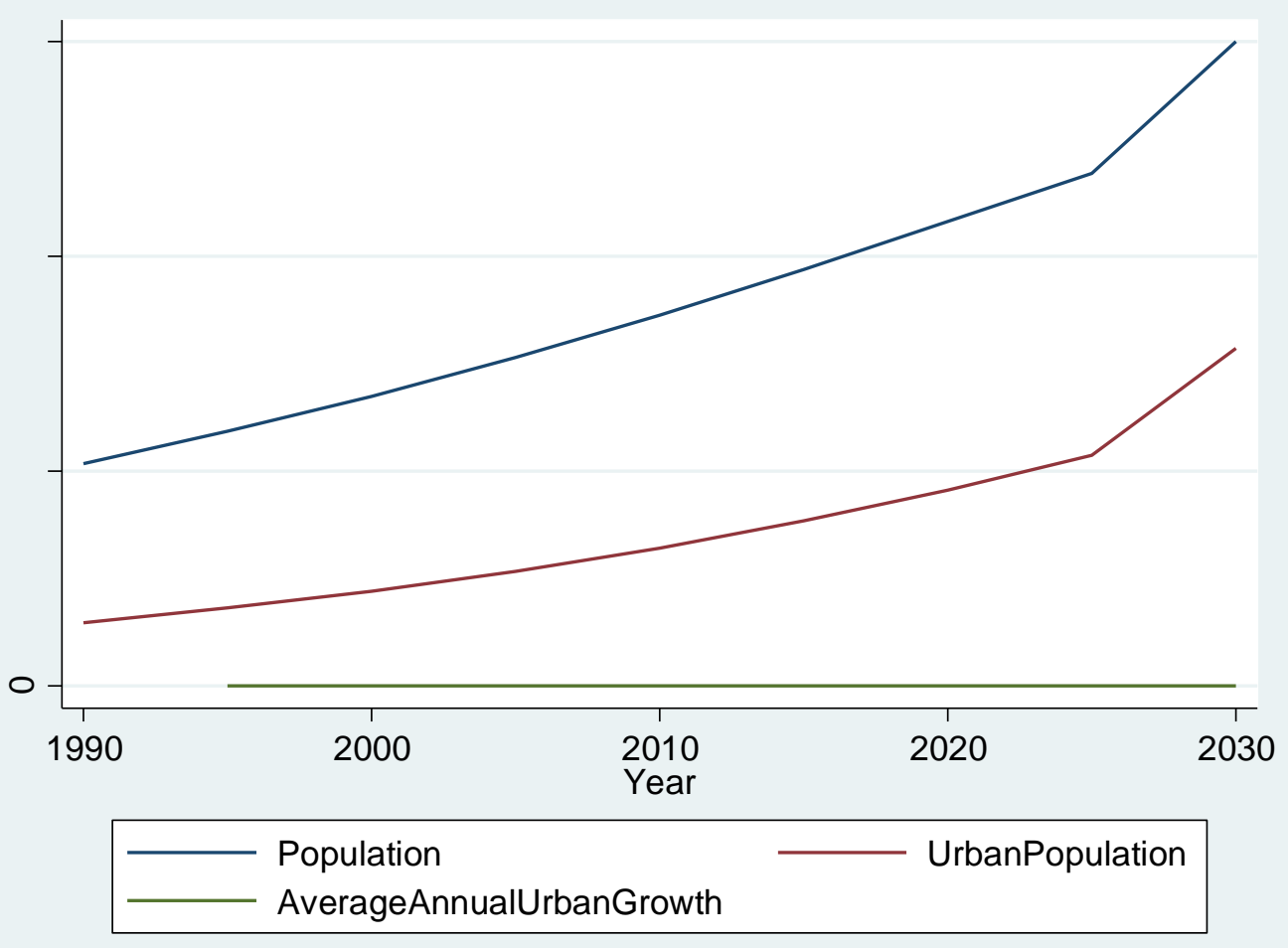

Sources: Author's representation of underlying data from UN-Habitat, (2010); Adegun (2011) and Jiboye (2011)

In absolute terms, an estimated 900 million new urban dwellers which is equivalent to what Europe, USA and Japan combined have managed over the past 265 years will emerge in Africa by 2050 (Mo Ibrahim Foundation, 2015). Urbanisation is both a problem and advantage to Africa's economic development (Tacoli et al., 2015; Collier, 2016). Urbanisation provides an opportunity to internalise economies of scale in the provision of basic infrastructure (water, health, education and electricity among others) (Carmody and Owusu, 2016). There is a dearth of opportunities in rural Africa which accounts for exodus of people to urban areas. The people gain improved access to employment opportunities and infrastructure (schools, electricity, water, health facilities etc.) (Opoko and Oluwatayo, 2014). There are pull and push factors influencing urbanisation in Africa (Freire 
et al., 2014). In Africa, the bulk of the people who moved into the urban areas were "pushed-out" of rural areas because of adverse climate change impacts resulting in low agricultural productivity and consequently low income. Another push factor is infrastructure deficits that characterise rural areas in Africa. The pull factors are the abundance of opportunities-employment and social services and glamour of city life. Urbanisation is an outcome of social, economic and political developments resulting in urban concentration and growth of large cities, changes in land use and transformation from rural to metropolitan pattern of organisation and governance (Ekpenyong, 2015).

Urbanisation becomes a problem when cities are not safe because of the one-way movement of people from rural to urban areas. Generally, migrants are scapegoated as the cause of insecurity confronting our world. African urban centres are characterised by kidnapping, terrorism, armed robbery and electoral violence among others. Migrants put pressure on the already stressed or inadequate infrastructure in cities. Only 38percent of the urban population in Africa have access to piped water networks (Mo Ibrahim Foundation, 2015). The level of indiscriminate disposal of toxic wastes into the environment is worrisome. Urban environment is characterised by pollutions from industries, traffic, residential congestion and lack of green parks (UNECA, 2014). According to Tabiajuka (2007), an estimated 72percent of the urban population in sub-Saharan live under sub-human conditions in slums and squatter settlement without adequate access to basic services. African cities have the $2^{\text {nd }}$ highest level of inequality in the World with urban Gini coefficient of 0.84 compared to the average of 0.4 (Mo Ibrahim Foundation, 2015; UNHabitat, 2015). In fact, one could be living in urban areas without gaining access to basic services e.g. health, education, water and improved sanitation among others (Ozden and Enwere, 2012). The facilities could be available while an average citizen lack economic access to them (Nordhag, 2012). Youth unemployment in Africa is 6 times higher in urban areas than in rural areas (Mo Ibrahim Foundation, 2015). Therefore, living in urban areas does not necessarily translate to better economic outcomes. Urban and rural areas are linked in the food security web. This is because increased food production in rural areas will result in low food prices in urban areas given transportation costs ceteris paribus. The population of farmers in rural Africa are aged owing to the migration of potential agricultural labour to urban areas. Therefore, urbanisation compound agricultural production problems since there is little to what the farmers can produce (Ackello-Ogutu et al., 2012). The risk aversion of farmers makes technology adoption difficult. Therefore, almost all the four pillars of food security are affected by urbanisation in Africa.

There is a large body of literature in economics which explained urbanisation in the context of spatial and demographic outcome of a broader process of structural transformation (Timmer, 2009; Djurfeldt, 2015). Labour and capital flow from agriculture to manufacturing and services in urban areas. This reduces the share of agriculture both in total value added and in the labour force in the process of economic growth (Djurfeldt, 2015). Urbanisation in the developed world resulted from increase in agricultural productivity which induced movement of people into labour markets in newly developed industries. In other words, a positive relationship exists between economic growth and societal development in developed countries (Nordhag, 2012). This is consistent with the earlier works of Arthur Lewis and Simon Kuznets (Christiaensen et al., 2013). In other words, it is believed that as people move out of agriculture to engage in economic activities off-farm and outside the rural communities, new opportunities are opened up. The opportunities include remittances, increased demands for agricultural output thereby igniting the process for economic growth and poverty reduction (Christiaensen et al., 2013). Africa's urbanisation is unplanned (Fox, 2013) and premature since it is not a product of agricultural growth (Tibajiuka, 2007; AFDB et al., 2016). To this end, Africa now witnesses "urbanisation of poverty" and new dimensions of crime (Christiaensen et al., 2013). Now that urbanisation is a reality of our time, global economic integration, improved trade, capital flows and Information Communication Technology (ICT) play an important role in integrating major cities and shaping the spatial organisation of cities (Jiboye, 2011).

\section{The ICT Revolution in Africa: A Problem or Way out of Urbanisation Challenges and Food Insecurity?}

Broadband penetration is currently low in Africa, but it is expected to rise steadily in the next few years (AFDB, 2011). The ICT penetration estimated at 7 percent in 2010 is expected to rise to 99percent of the population in 2060 (AFDB, 2011). African cities are built around large system of interconnected networks with regards to flow of labour, raw materials and other resources from rural areas (Dodman et al., 2016). Proper management of urbanisation is critical to economic development (Nordhag, 2012; Collier, 2016). Over time, countries that 
have reached OECD level of prosperity had successful urbanisation (Collier, 2016). There is a need for connectivity between the producers or firms and the market. Rural Africa is predominantly agricultural and as such needs to be well connected to the industries. Producers need to be connected with consumers given their changing needs such that they can transact in the market (Collier, 2016).

Urbanisation is key to good spatial connectivity as it generates connectivity in two ways. Urbanisation reduces distance between household and firms and cost of transport per unit of distance between them (Collier, 2016). Information Communication and Technology provides a platform where information on transactions, new business prospects, opportunities and market information can be generated, shared and reviewed on some devices including phones, computers, and internet among others. The world without borders and significant reductions in distance is emerging. Although, the state of infrastructure in Africa is not commendable, ICT provides a way out of most of the current challenges. The ICT revolution is based on quality information efficiently disseminated at the right time. Many scholars have argued that the African agricultural system needs a total overhaul in order to achieve food security. ICT can be used to gather, analyse and interpret information on the existing agricultural practices with the aim of proffering far-reaching solutions to age-long problems. There are improved strains of livestock and varieties of crops that did not go beyond the researchers' farm plots in Africa. The ailing agricultural extension system suffering from inadequate man power and unattractive conditions is not able to guide adoption process of improved agricultural practices and inputs. On the other hand, farmers face challenges in getting their goods to the market owing to infrastructure deficit. Due to high moisture content, bulkiness and perishability that characterise agricultural products, farmers are forced to sell at low prices to middlemen. ICT can provide a platform for farmers to gain better access to markets and reorganise their farm operations to accommodate market dynamics. According to Mafusire et al. (2010), Africa requires about USD93 billion of investment to meet the funding needs in ICT, irrigation, power, transport, water and sanitation infrastructure. ICT especially mobile networks that are currently growing exponentially in Africa can be harnessed in bridging food gaps and urbanisation issues in Africa. ICT can also be used in crime control and maintaining law and order.

\section{Conclusion and Recommendations}

The paper examined food security and urbanisation within the context of ICT revolution in Africa. We found that urbanisation and agricultural productivity have bi-causal relationship. There is no way food security will be attained if agricultural productivity is low in Africa. The bulk of the people are food insecure due to some undermining factors of agricultural productivity. The factors include undercapitalisation, climate change, inadequate access to improved technologies and low adoption of improved agricultural practices. As a result of this, people move from rural to urban Africa thereby increasing the proportion of the population that is urban. The paper found that urbanisation can both be a challenge and opportunity depending on how it is managed. The level of ICT use in Africa is still low but it is projected to increase significantly in future. ICT can be used to provide market information to farmers with regards to sourcing of improved inputs and getting good markets for agricultural products. ICT can also be deployed to climate change adaptation through weather forecasts and advice towards building climate resilient systems. From the foregoing, the following policy prescriptions are suggested:

- African governments should plan urbanisation such that cities will have master plans to be adhered to by all developers towards reducing slums.

- Government and private organisations should increase and monitor investments in infrastructure (roads, schools, hospitals, electricity, potable water etc.) in order to make rural areas more attractive and reduce unplanned migration

- Farmers should adopt improved technologies towards mitigating climate change impacts in order to enhance agricultural productivity.

- There is the need for government to provide enabling environments where industries can thrive if the much desired improvement in youth employment especially in African major cities is anything to go by. 


\section{References}

Ackello-Ogutu C., Okoruwa V and Bahal, G.N. (2012). Long Term Challenges to Food Security and Rural Livelihood in Sub-Saharan Africa. A policy research paper prepared for Global Development Network (GDN), 1-54.

Adegun, O. B. (2011). Shelter and the Future African City. The Built and Human Environment Review, 4 (2):3340.

(AFDB) African Development Bank (2011). Africa in 50 Years' Time: The Road towards Inclusive Growth, 1-76.

(AFDB) African Development Bank, (OECD), (UNDP) United Nations Development Programme (2016). Sustainable Cities and Structural Transformation, 1-131.

Bremner J. (2012). Population and Food Security in Africa: Africa's Challenge, 1-6.

Carmody, P. and Owusu, F. (2016). Neoliberalism, Urbanisation and Change in Africa: The Political Economy of Heterotopias. Journal of African Development, 18: 61-73.

Chenal, J. (2016). Capitalizing on Urbanisation: The Importance of Planning, Infrastructure and Finance for Africa's Growing Cities, 1-16.

Christiaensen, L., J. De Weerds and Todo, Y. (2013). Urbanisation and Poverty Reduction: The Role of Rural Diversification and Secondary Towns. World Bank Policy Research Paper 6422, 1-37.

Collier, P. (2016). African Urbanization: An Analytic Policy Guide. A Paper Submitted to DFID, 1-38.

Conceicao P., L. Horn-Phathanothai and Ngororano, A. (2011). Food Security and Human Development in Africa: Strategic Considerations and Directions for Further Research, 1-15.

Djurfeldt, A.A. (2015). Urbanization and linkages to smallholder farming in sub-Saharan Africa: implications for food security. Global Food Security, 4, 1-7. DOI: 10.1016/j.gfs.2014.08.002

Dodman, D., H. Leck, M. Rusca and Colenbrader, S. (2016). African Urbanisation and Urbanism: Implications for risk accumulation and reduction. Economic and Social Research Council Working Paper 10, 1-34.

Ekpeyong, A.S. (2015). Urbanisation: Its Implication for Sustainable Food Security, Health and Nutritional Nexus in Developing Economies-A Case Study of Nigeria. Journal of Studies in Social Sciences, 11(1):2949.

(FAO) Food and Agricultural Organisation (2015). Food Security and Humanitarian Implications in West Africa and The Sahel. FAO Working Paper Number 63, 1-6.

(FAO) Food and Agricultural Organisation, (IFAD) International Fund for Agricultural Development and (WFP) World Food Programme (2014). The State of Food Insecurity in the World, 1-57.

Fox, S.R. (2013). The Political Economy of Urbanisation and Development in sub-Saharan Africa. A Doctor of Philosophy Thesis submitted to the Department of International Development of the London School of Economics, 1-166.

Freire, M.E., S. Lall and Leipziger, D. (2014). Africa's Urbanization: Challenges and Opportunities. The Growth Dialogue Working Paper Number 7, 1-44.

Harris, K. (2014). Bread and Freedom: Linking Democracy and Food Security in Sub-Saharan Africa. African Studies Quarterly, 15(1):13-35.

Hove, M. E.T. Ngwerume and Muchemwa, C. (2013). The Urban Crisis in sub-Saharan Africa: A Threat to Human Security and Sustainable Development. Stability, 2(1):1-14.

(ICAIDS) Interagency Coalition on AIDS (2001). HIV/AIDS and Food Security, 1-4.

International Food Policy Research Institute (IFPRI) (2012). 2011 Global Food Policy Report. IFPRI, Washington, DC Historical Perspective. Washington D.C.: The American Enterprise Institute Press.

International Fund for Agricultural Development (IFAD) (2011), Horn of Africa: The Rains will Fall in 2015, 2016, or 2017, But Must We Also Fail? Retrieved on June 11, 2012 from https://www.ifad.org/newsroom/press_release/past/tags/y2011/1914219.

Jelili, 0. (2012). Urbanization and Future of Cities in Africa: The Emerging Facts and Challenges to Planners. Global Journal of Human Social Science, 12(7):1-7.

Jiboye, D. A. (2011). Sustainable Urbanisation: Issues and Challenges for Effective Urban Governance in Nigeria. Journal of Sustainable Development, 4(6):211-224.

Kanayo O. (2014). Poverty Incidence and Reduction Strategies in Nigeria: Challenges of meeting 2015 MDG Targets. Journal of Economics, 5(2), 201-217.

Lwasa, S. (2014). Managing African Urbanization in the Context of Environmental Change. Interdiscipline, 2(2):263-280.

Mafusire, A., J. Anyanwu, Z. Brixiova and Mubila, M. (2010). Infrastructure Deficit and Opportunities in Africa. African Development Bank Economic Brief, 1, 1-16. 
Masters, L. (2008). The Global Food Crisis and the Challenge of Food Security. Africa Institute of South Africa (AISA) Policy Brief 3, 1-8.

Mo Ibrahim Foundation (2015). Facts and Figures: African Urban Dynamics, 1-92.

Nordhag, M. (2012). Urbanisation in sub-Saharan Africa. A Bachelor Thesis submitted to the Department of Peace and Development Studies, Linneaus University, 1-110.

Ogujiuba K., U.M. Ogbonnaya and Abraham, T.W. (2013). Comparative Analysis of Arab Spring Determinants. African Security Review, 22(4), 1-9.

Oluwatayo I.B. and Ojo, A.O. (2016). Awareness and Adaptation to Climate Change among Yam-Based Farmers in Oyo State, Nigeria. Journal of Developing Areas, 50(2):97-108.

Opoko, P.A. and Oluwatayo, A. (2014). Trends in Urbanisation: Implication for Planning and Low-Income Housing Delivery in Lagos, Nigeria. Architectural Research, 4(1A):15-26.

Ozden, K. and Enwere, C. (2012). Urbanisation and its Political Challenges in Developing Countries. Eurasian Journal of Business and Economics, 5(10): 99-120.

Ruhiiga, T.M. (2013). Managing Explosive Urbanisation in Africa. Journal of Human Ecology, 42(1):43-52.

Ringler C., T. Zhu, X. Cai, J. Koo and Wang, D. (2010). Climate Change Impact on Food Security in Sub-Saharan Africa: Insights from Comprehensive Climate Change Scenarios. IFPRI Discussion Paper No. 1042, 110.

(SDSN) Sustainable Development Solutions Network (2013). Solutions for Sustainable Agriculture and Food System. Technical Report for the Post-2015 Development Agenda, 1-108.

Tacoli, C., G. McGranahan and Satterthwaite, D. (2015). Urbanisation, Rural-Urban Migration and Urban Poverty. IEED Working Paper, IIED, London, 1-35.

Tibajiuka, A. K. (2007). Africa on the Move: An Urban Crisis in the Making. A contribution to the UN-Habitat Twenty First Session of the Governing Council, 16-20 April 2007, Nairobi, Kenya, 1-23.

Timmer, P., (2009). A World without Agriculture. The Structural Transformation Process in Historical Perspective. Washington D.C.: The American Enterprise Institute Press.

Ubong, B., N.S. Oguzor, and Wokocha, A. M. (2009). Educating People for Food Security to Avert Food Crisis: The Case of Nigeria. Bulgarian Journal of Science and Education Policy, 3(1):1-13.

(UN) United Nations (2009). The Millennium Development Goals Report, 2009.

(UNDESA) United Nations, Department of Economic and Social Affairs, Population Division, (2012). World Urbanization Prospects: The 2011 Revision. United Nations Population Division Department of Economic and Social Affairs.

(UNECA) United Nations Economic Commission for Africa (2014). Sustainable Urbanisation in Africa, 1-8.

UNHabitat (2015). Expert Meeting on Leveraging Urbanization for Development in Africa, 1-7.

United Nations Human Settlement Programme (2010). The State of African Cities. Governance, Inequality and Urban Land Markets. United Nations HABITAT. Nairobi.

Waugh D. (1990). Geography: Integrated Approach, UK, Thomas Nelson and Sons Limited, pp350-351.

(WHO) World Health Organisation (1996) Micronutrient Malnutrition: Half the World's Population Affected. WHO, 78, 1-14. 